\title{
10. SEISMIC PROFILES MADE UNDERWAY ON LEG 22
}

\author{
John J. Veevers, School of Earth Sciences, Macquarie University, \\ North Ryde, N.S.W., Australia
}

\section{INTRODUCTION}

Seismic profiles were made along the track of the Glomar Challenger on Leg 22 to reveal the regional acoustic stratigraphy and its relationship to the sections penetrated in the drill holes. The profiles of the drilling sites are described elsewhere. In this report, the regional stratigraphy is described and, where appropriate, related to the stratigraphical units penetrated in the drill holes:

\section{Methods}

Satisfactory profiles were made at the ship's average speed of 9.5 knots between drilling sites. On approaching the drilling site, the ship was slowed to 5 or 8 knots so that clearer profiles could be made. The sound sources were two Bolt $600 \mathrm{~A}$ air guns. A 5- or 10-cubic inch gun was strung 30 meters behind the ship, and a 30-cubic inch gun was strung 15 meters behind. The receiving system was an eel of twenty MP16-17 hydrophones in series-parallel strung 300 meters behind. Two recorders were used. One (Edo 333 B-1) was set with a 10-sec sweep and filters at $80-2560 \mathrm{~Hz}$, and the other (Edo $333 \mathrm{C}-4$ ) with a 3-sec sweep and filters at $40-320 \mathrm{~Hz}$. The vertical exaggeration of the sea floor profile is $28.5: 1$. Sonobuoys were used in attempts at recording wide-angle reflections but were unsuccessful.

\section{Nomenclature}

Physiographic names are from Heezen and Tharp (1966) and Laughton, Matthews, and Fisher (1970), unless attributed otherwise. Within each physiographic province, reflectors were numbered serially from the sea floor downwards except where reflectors had been named from previous studies. The numbers carry no implied identification of reflectors outside their physiographic province.

\section{Illustrations}

Figure 1 shows the ship's track and the physiographic provinces. Figure 2 is comprised of line drawings of the 10 -sec sweep profiles supplemented by photocopies of selected records (Figures 3-6). All this information is summarized in Figure 8.

\section{DARWIN TO SITE 211}

The track runs westward across the wide margin of northwest Australia and then across the Argo Abyssal Plain, Roo Rise, and Christmas Rise to the fairly flat area of Site 211 at the eastern margin of the Cocos Basin.

\section{Northwest Australian Margin}

The profile of the continental margin is typical for this area and shows clearly the Reflectors $\left(\mathrm{R}_{1}, \mathrm{R}_{2}, \mathrm{R}_{4}\right)$ and physiographic units distinguished by Falvey and Veevers (in prep.) and Veevers et al. (in prep.). These authors interpret
$\mathrm{R}_{4}$ as an angular unconformity near the CretaceousCenozoic boundary and $R_{2}$ and $R_{1}$ as surfaces high in the Cenozoic. Except for a minor divergence at the upper slope, the sea floor and the subbottom structure are parallel. The Cenozoic section crops out at the seaward edge of the Scott Plateau, and is repeated in two graben beneath the lower slope (Figure 3A). The rest of the lower slope is mantled by a thin layer of sediment. The continental rise consists of a ridge with an east-facing slope covered with sediment and a bare steep west-facing face, and a series of three west-facing scarps that rise above the flank of the Argo Abyssal Plain.

\section{Argo Abyssal Plain (Figure 3 A-D)}

The next part of the track crosses the complex northern flank of the Argo Abyssal Plain, beneath which two reflectors ( $\mathrm{L}$ and $\mathrm{M}$ ) recognized by Veevers et al. (in prep.) and a third (J) were traced.

Reflector L, the top of a transparent section, generally parallels $\mathrm{M}$ and is overlain by a set of strong reflectors that includes $\mathrm{K}$ (not shown) and whose top is J. From J to the sea floor is a transparent layer. The set of strong reflectors bounded by $\mathrm{J}$ and $\mathrm{L}$ is interpreted as a ponded turbidite sequence (Ewing et al., 1969, p. 237, describe the topmost sediment of the basins adjacent to the north and west margins of Australia as "a thin turbidite layer about $0.1 \mathrm{sec}$ thick") and the section from L to $\mathrm{M}$ as clay or biogenous ooze. By comparison with the sequence penetrated at Site 211 , the layer from $\mathbf{J}$ to the sea floor is tentatively identified as volcanic ash and siliceous ooze. Reflector M has a rough outline that simulates that of 'normal' oceanic basement (Layer 2).

The flank of the plain is fairly flat between 2130 hours 16 January 1972 and 0800 hours 17 January 1972 . West of this, the flank is broken into an undulating surface with relief of $0.7 \mathrm{sec}$. The first rise, between 0800 and 1000 hours 17 January 1972, brings Reflector M close to the surface. The presumed turbidite sequence recurs west of this rise and extends to 1330 hours 17 January 1972 where it either wedges out against a low rise or is broken up beyond recognition by several parallel-sided bodies, presumably of cylindrical shape.

This profile differs from others (Vema-20, Vema-28) taken in the immediate area in showing so many cylinders, but, like them, it does not reveal their composition, whether igneous rock, shale, or plastic clay. Magnetic anomalies do not indicate igneous rock. The smaller cylinders are only a few hundred meters across and have regular parallel sides. The larger bodies are several kilometers across, and their sides taper upwards. All are acoustically transparent, and most lie above rises in reflector M. At 0240 hours 18 January 1972 , M appears to be split by a transparent zone immediately beneath an outcropping cylinder. As a result of the disturbances caused 


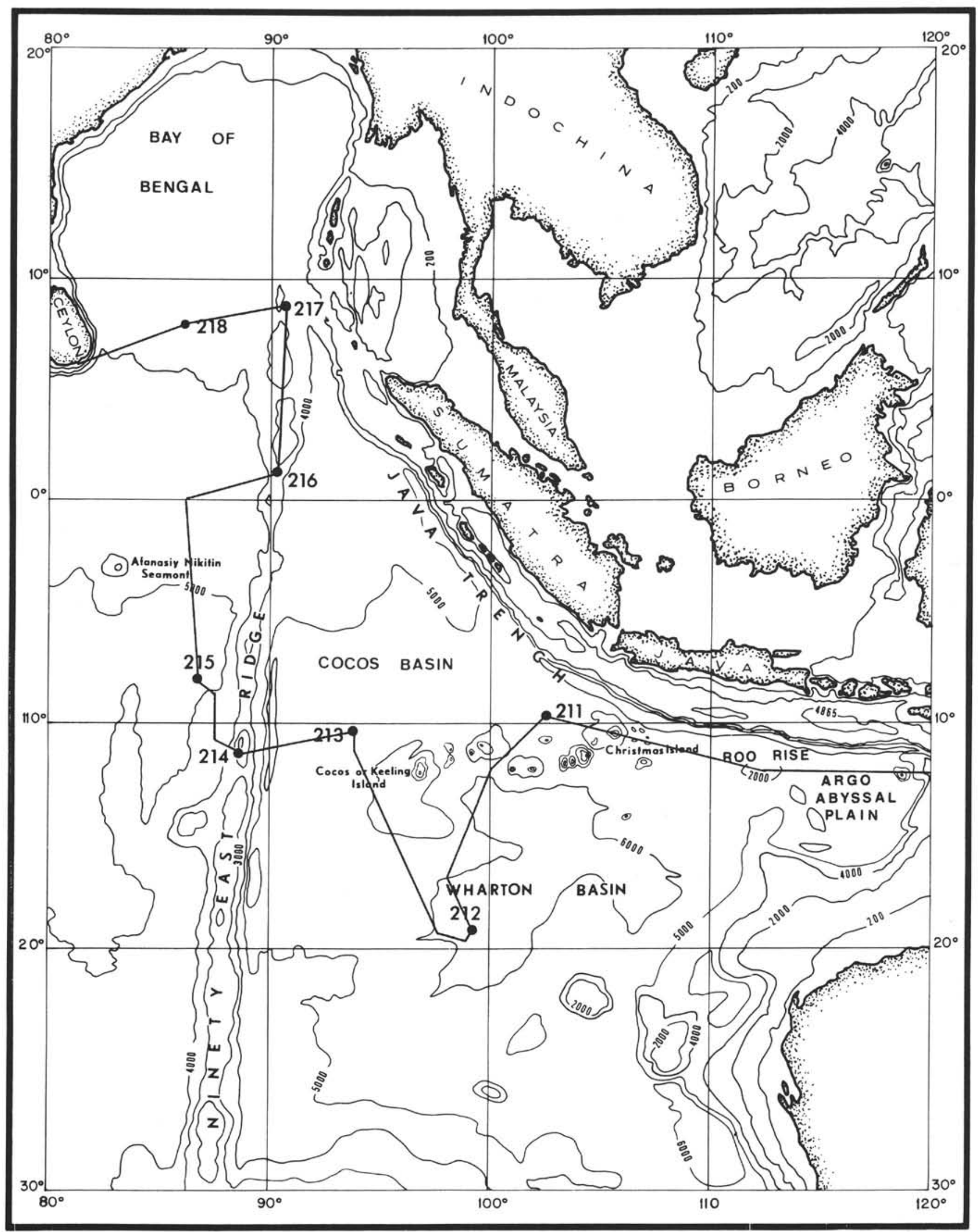

Figure 1. Locality map, showing ship's track, bathymetry $(m)$, and physiographic provinces. After Bathymetric map of Indian Ocean (original scale 1:15 million), Central Headquarters, Geodesy and Cartography, State Geological Commission of USSR, Moscow, 1963. 


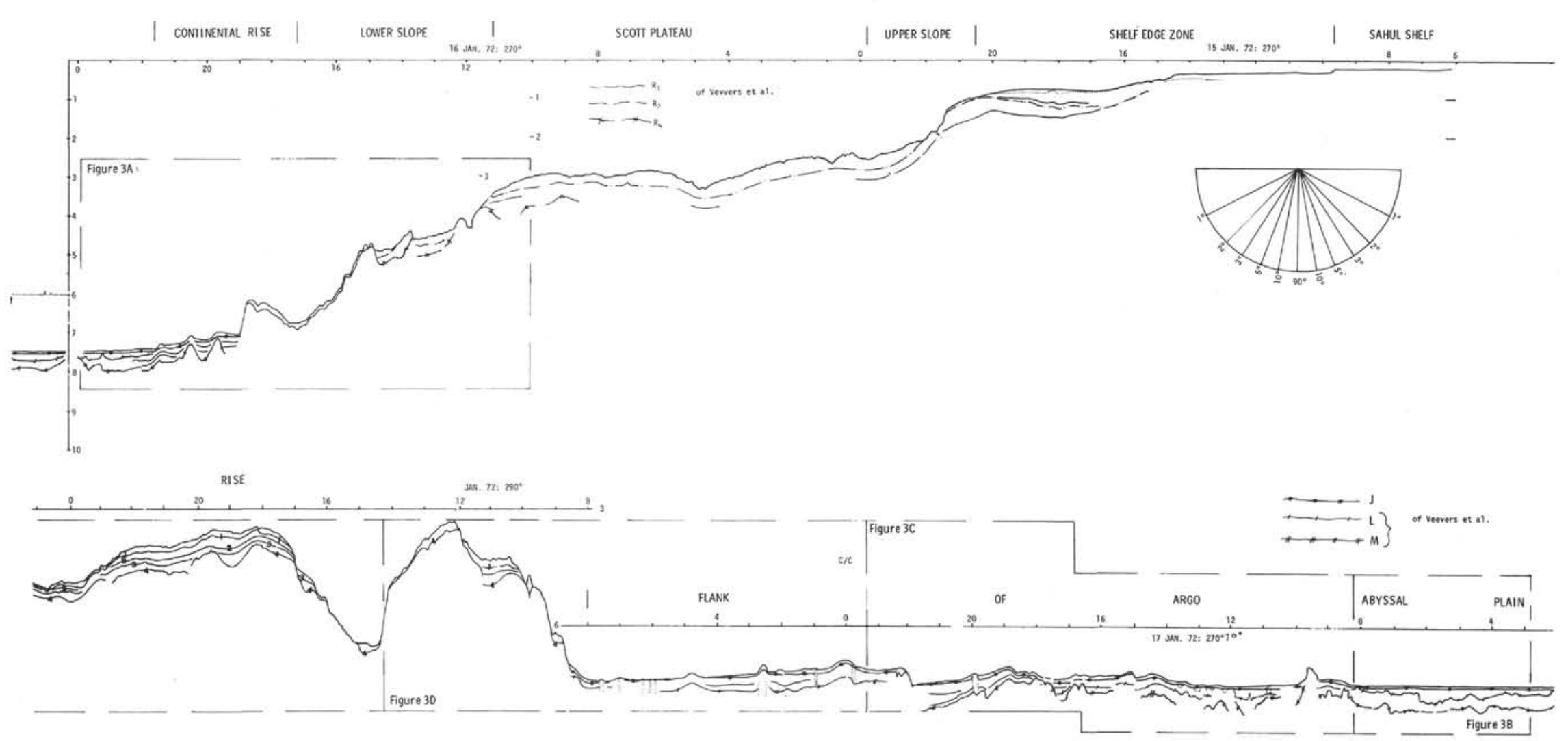

Figure 2. Line drawings of seismic profiles. Hour marks along track related to average speed of 9.5 knots. Depth in seconds of two-way reflection time. Boxed parts refer to original records reproduced in Figures 3 to 6. 

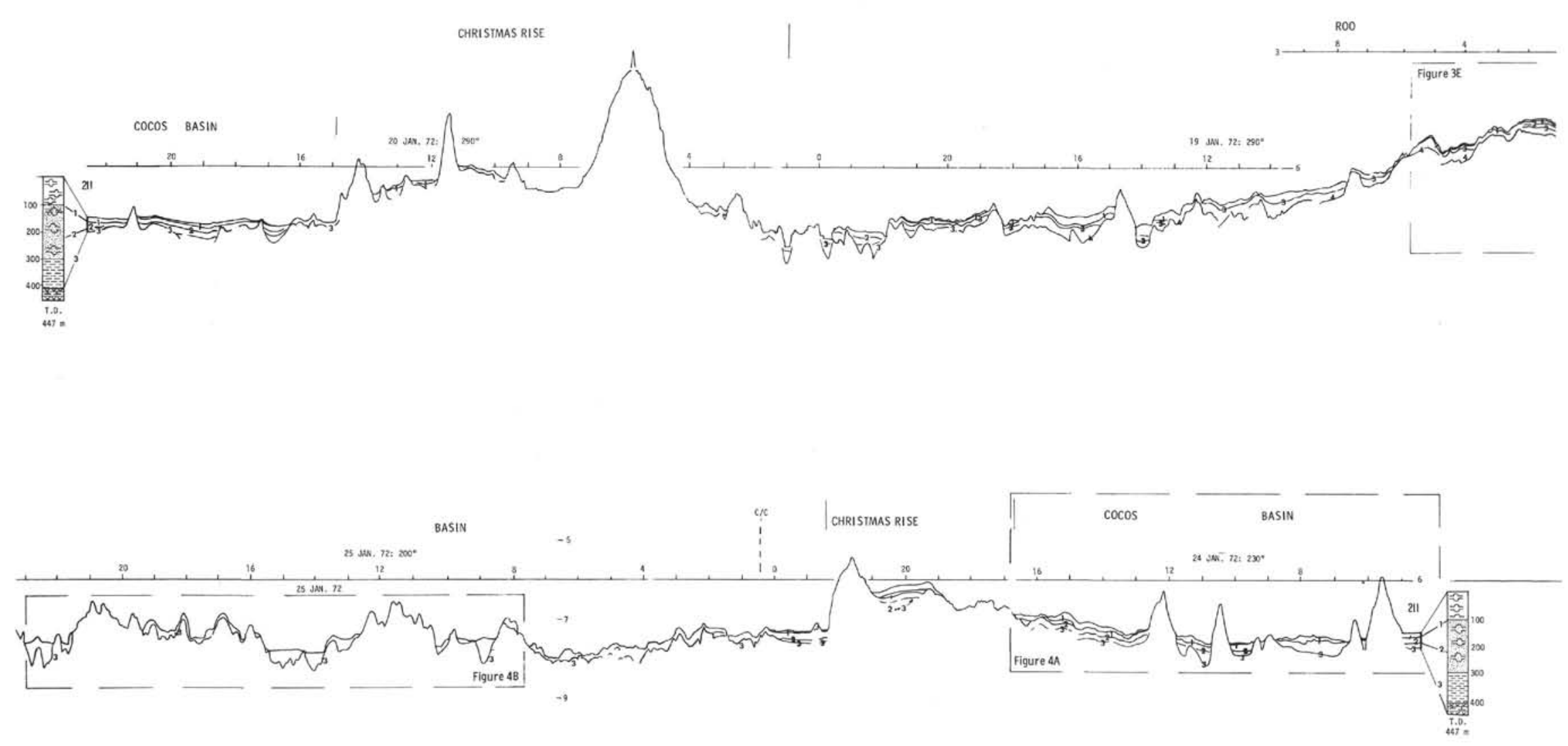

Figure 2. (Continued). 


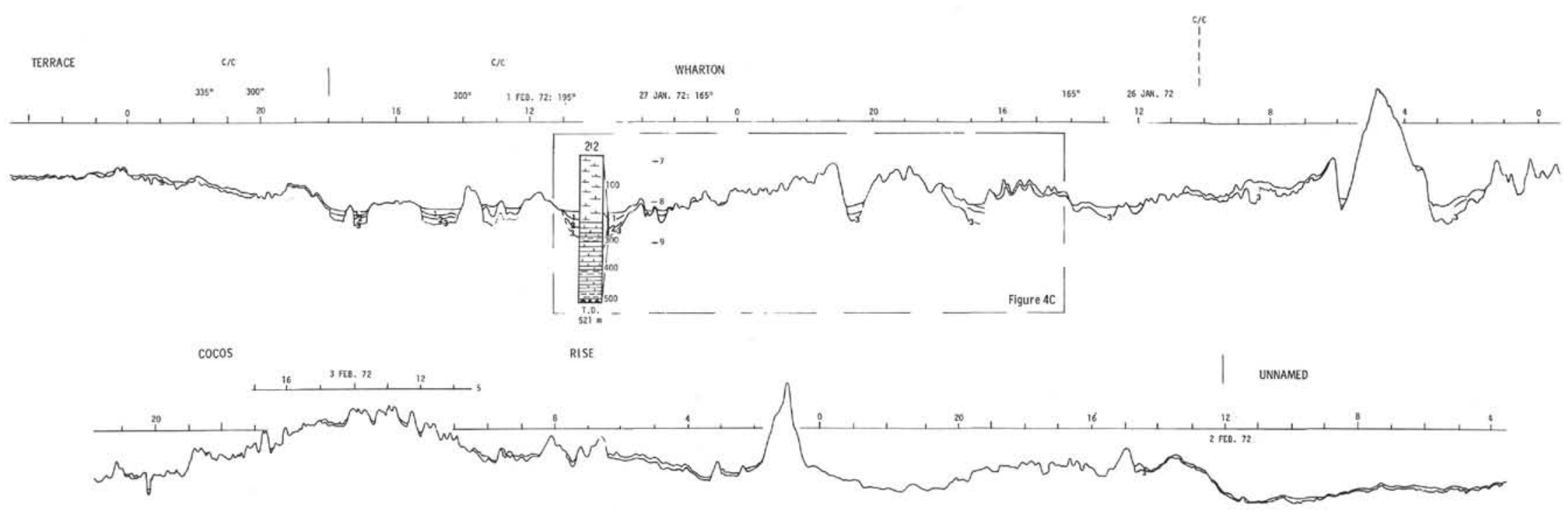

Figure 2. (Continued). 


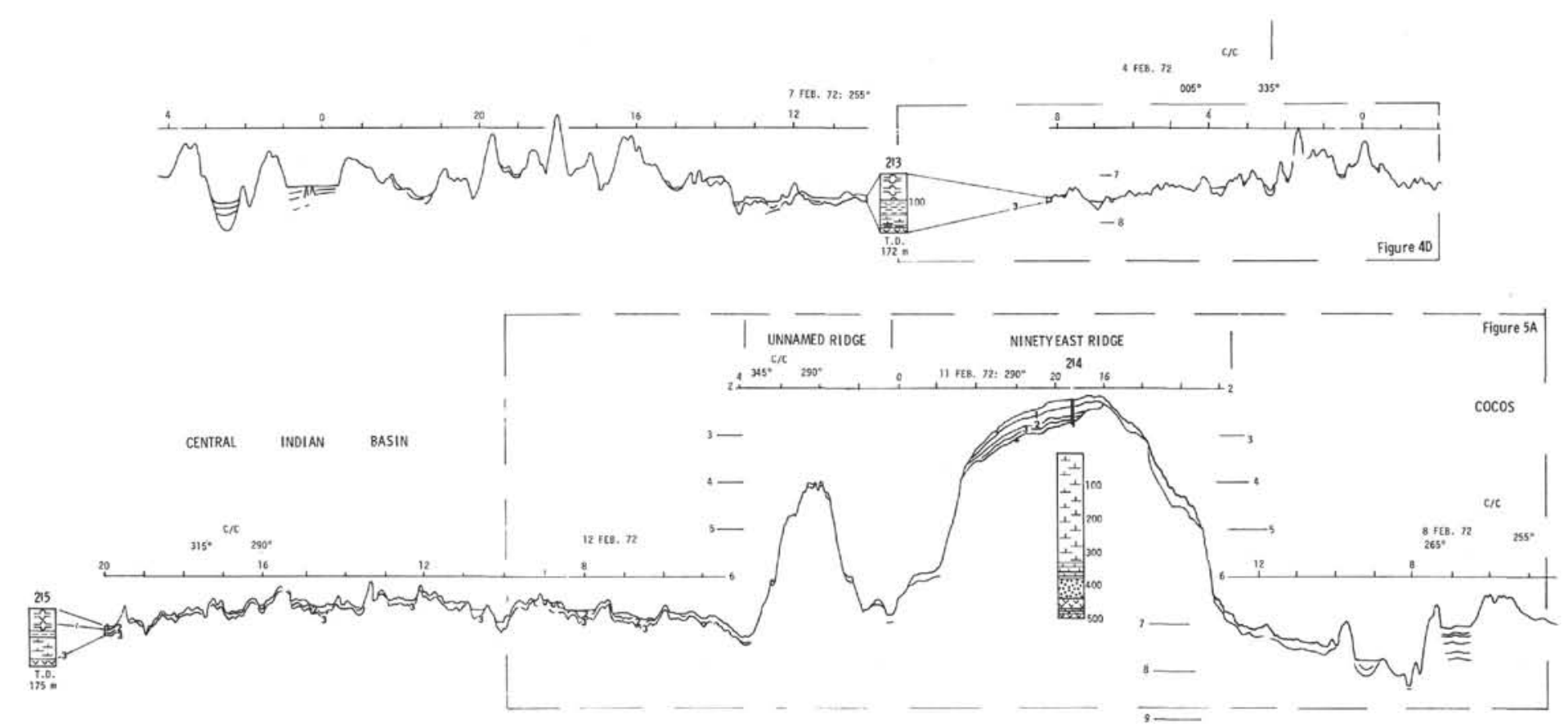

Figure 2. (Continued). 


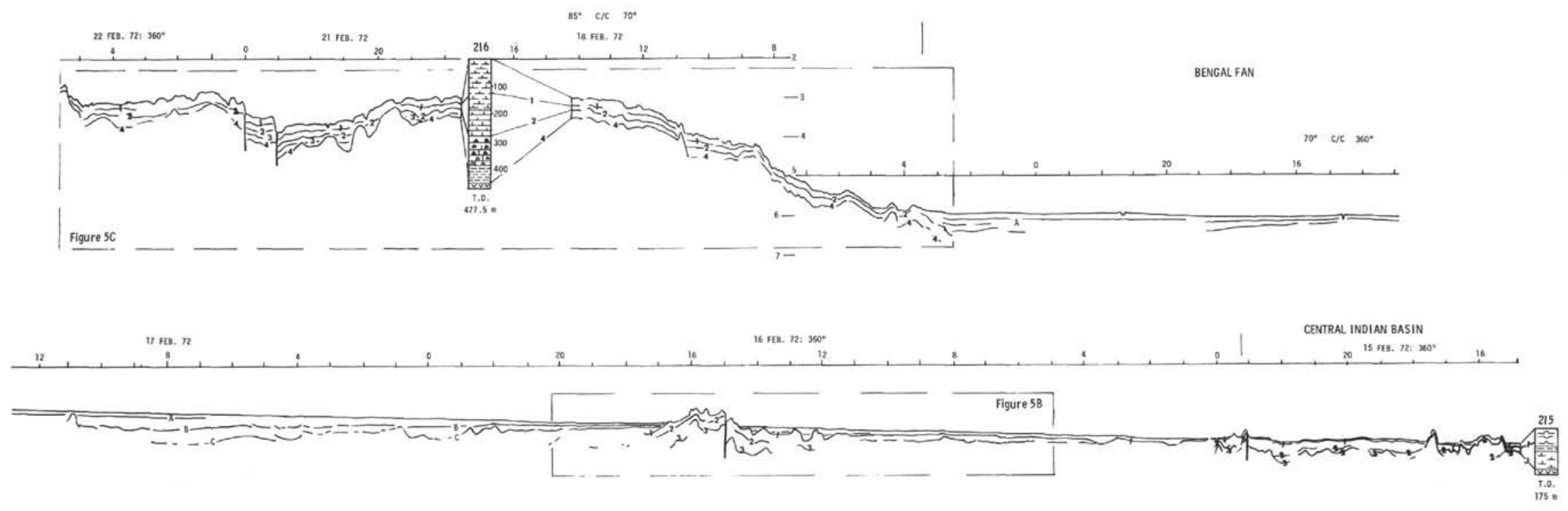

Figure 2. (Continued). 

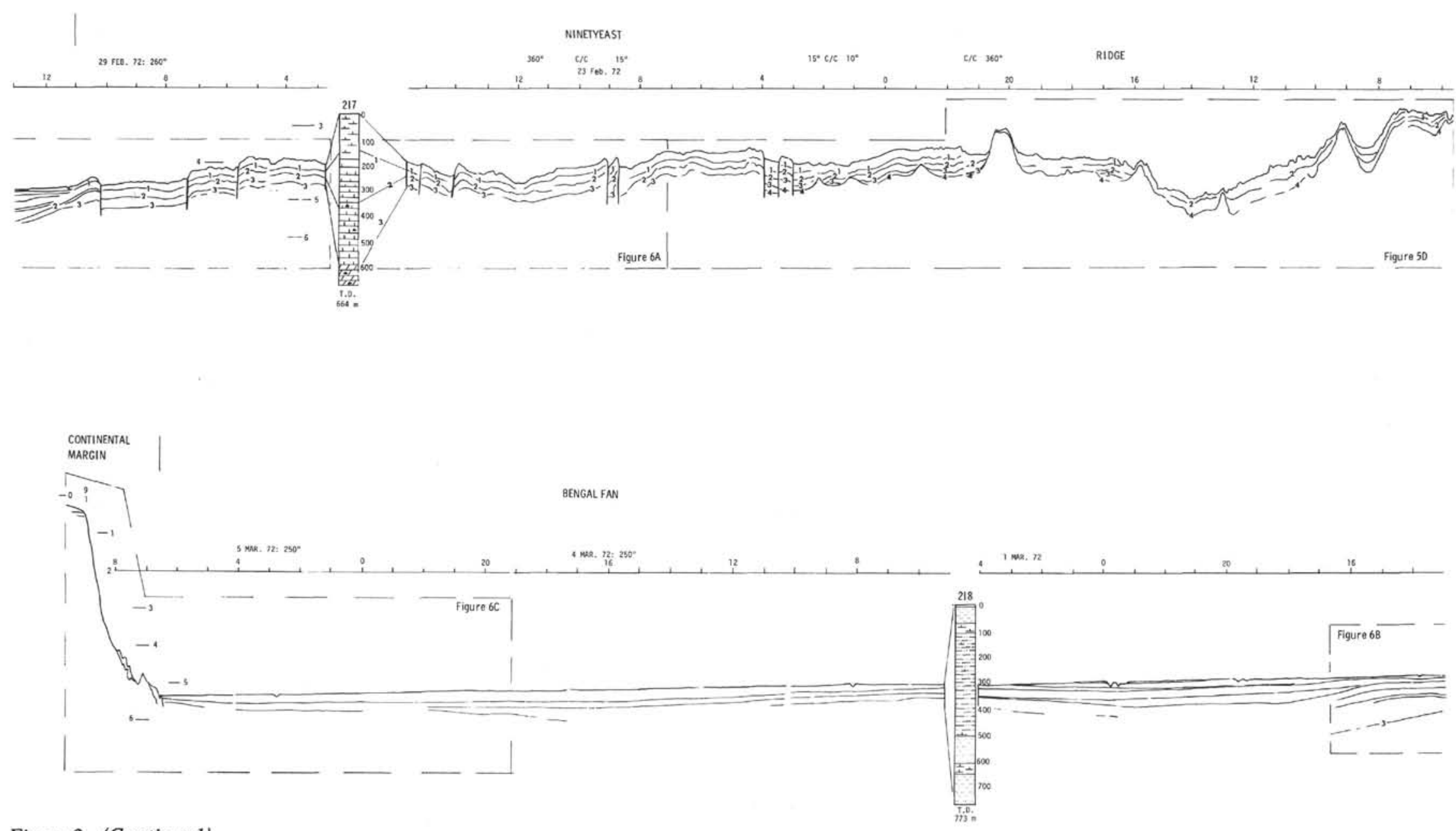

Figure 2. (Continued). 

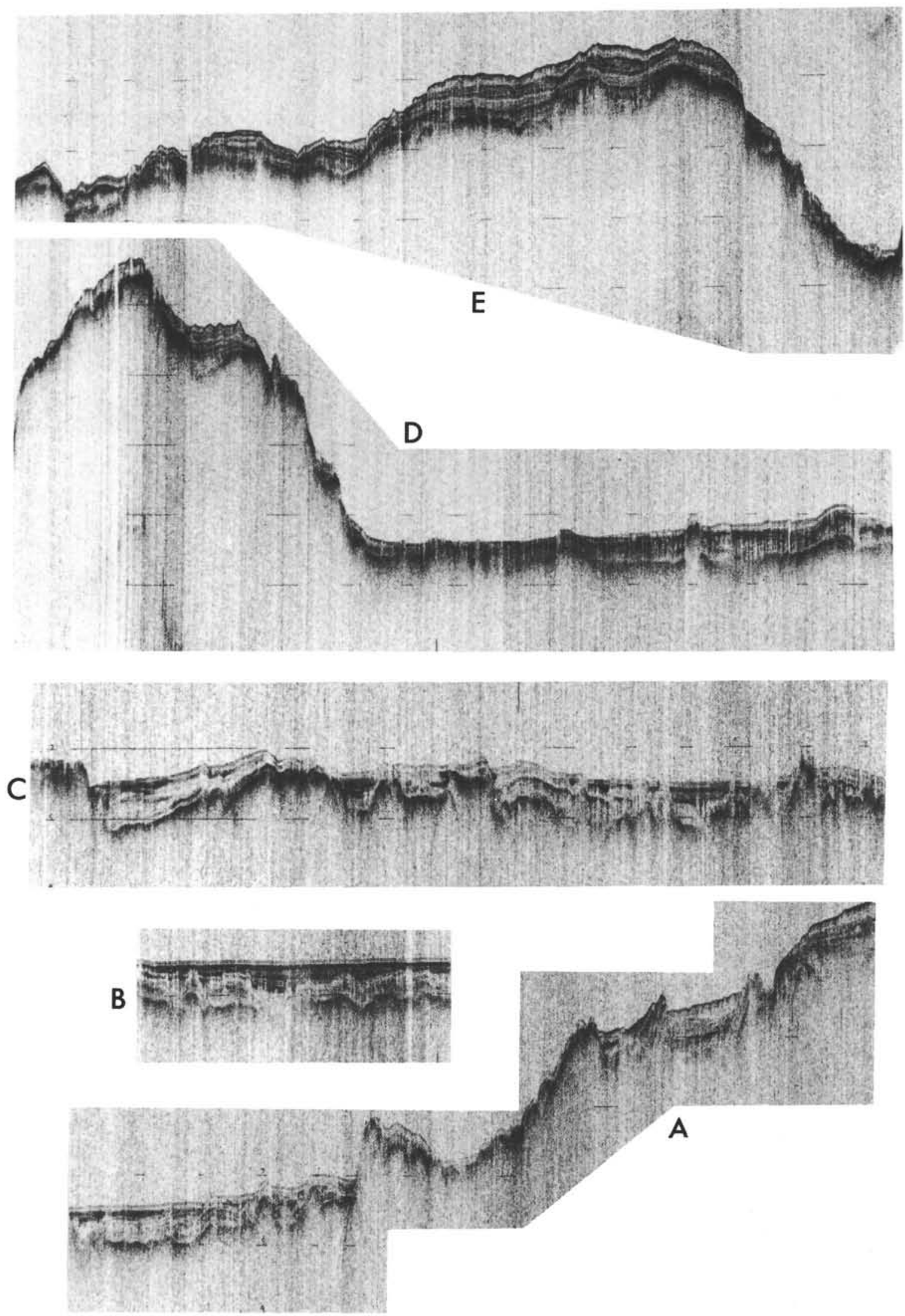

Figure 3. Reproductions of original records of northwest Australian margin, Argo Abyssal Plain, and Roo Rise. Details shown in the line drawings of Figure 2. A to E are continuous except for a gap of 3 hours between A and B. Each photograph joins its left-hand side below with the right-hand side of the photograph above. 

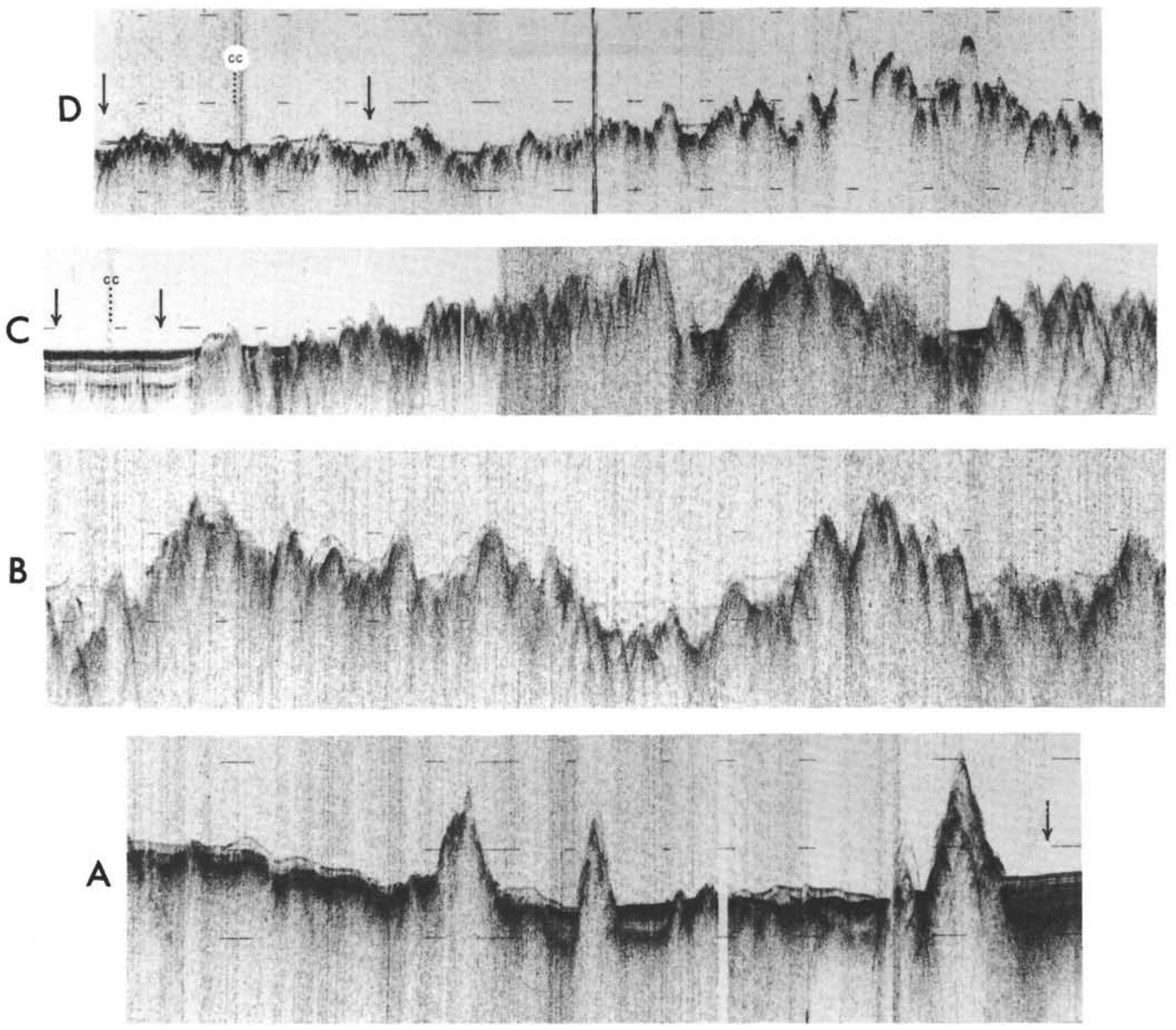

Figure 4. Reproductions of original records of the Cocos and Wharton basins. Details shown in the line drawings of Figure 2. A: Site 211 (arrowed) and approaches. Records shown here, but not in Figure 2, are traverses additional to the direct track to locate the drilling sites. B: transparent sediment over rough basement topography. C: Site 212 (arrowed) and approaches. D: Site 213 (arrowed) and approaches.

by the intrusion of the cylinders, Reflector $\mathrm{L}$ is not recognizable west of 1730 hours 17 January 1972 . Reflector $\mathrm{J}$ can be traced westward continuously except where it laps against a mound at 0445 hours 18 January 1972.

\section{Roo Rise (Figure 3D, E)}

The northwest flank of the Argo Abyssal Plain terminates against the Roo Rise, which comprises a western plateau that slopes westward and an eastern ridge. The ship's track crossed the crest of the rise, whose maximum relief is thus seen to be $3 \mathrm{~km}$. A sequence of well-stratified sediments up of 0.8 -sec thick mantles the rise. The eastern flank of the rise and the lower half of the walls of the valley that separates the ridge from the plateau are virtually bare of sediment. A reflector (1) at the base of the transparent surface layer is underlain by several bands of reflectors from which reflectors 2 and 3 are depicted on the drawing. All these sediments are draped over the lowest reflector (4). The interval between reflectors 3 and 4 thins westward to the foot of the Christmas Rise at a depth of $8 \sec (6000 \mathrm{~m})$ at 0100 hours 20 January 1972.

Heezen and Tharp (1966) show a rise between the Roo and Christmas Rises called the Karma Rise, whose mapped position lies across the ship's track. In fact, the Karma Rise must lie wholly south of the ship's track because the profile of this area shows a depression with a few low hills.

\section{Christmas Rise}

Where crossed by the Glomar Challenger, the crest of the Christmas Rise is symmetrical, sharp-crested, and devoid of sediment. Its western flank is comprised of several ridges with sediment-filled valleys in between. Reflector 1 is the 

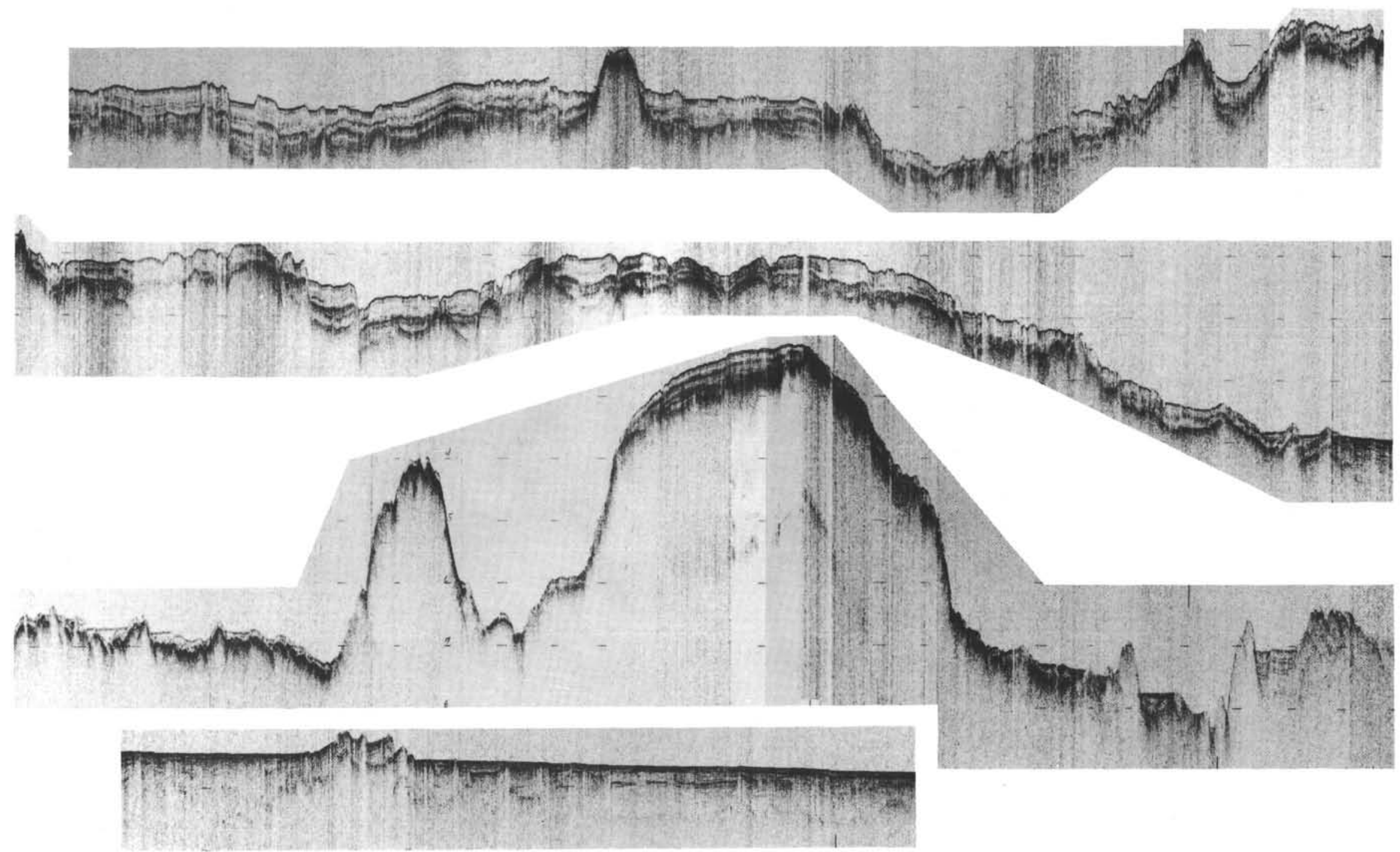

Figure 5. Reproductions of original records of the Ninetyeast Ridge and flanking areas. A: cross section of Ninetyeast Ridge, showing Site 214 (arrowed). B: southern part of Bengal Fan. C: edge of Bengal Fan overlying western flank of Ninetyeast Ridge, Site 216 (arrowed-note additional traverse between arrows), and northern continuation of ridge, continuous with $\mathrm{D}$ (and Figure $6 \mathrm{~A}$ ). 


\section{J. J. VEEVERS}

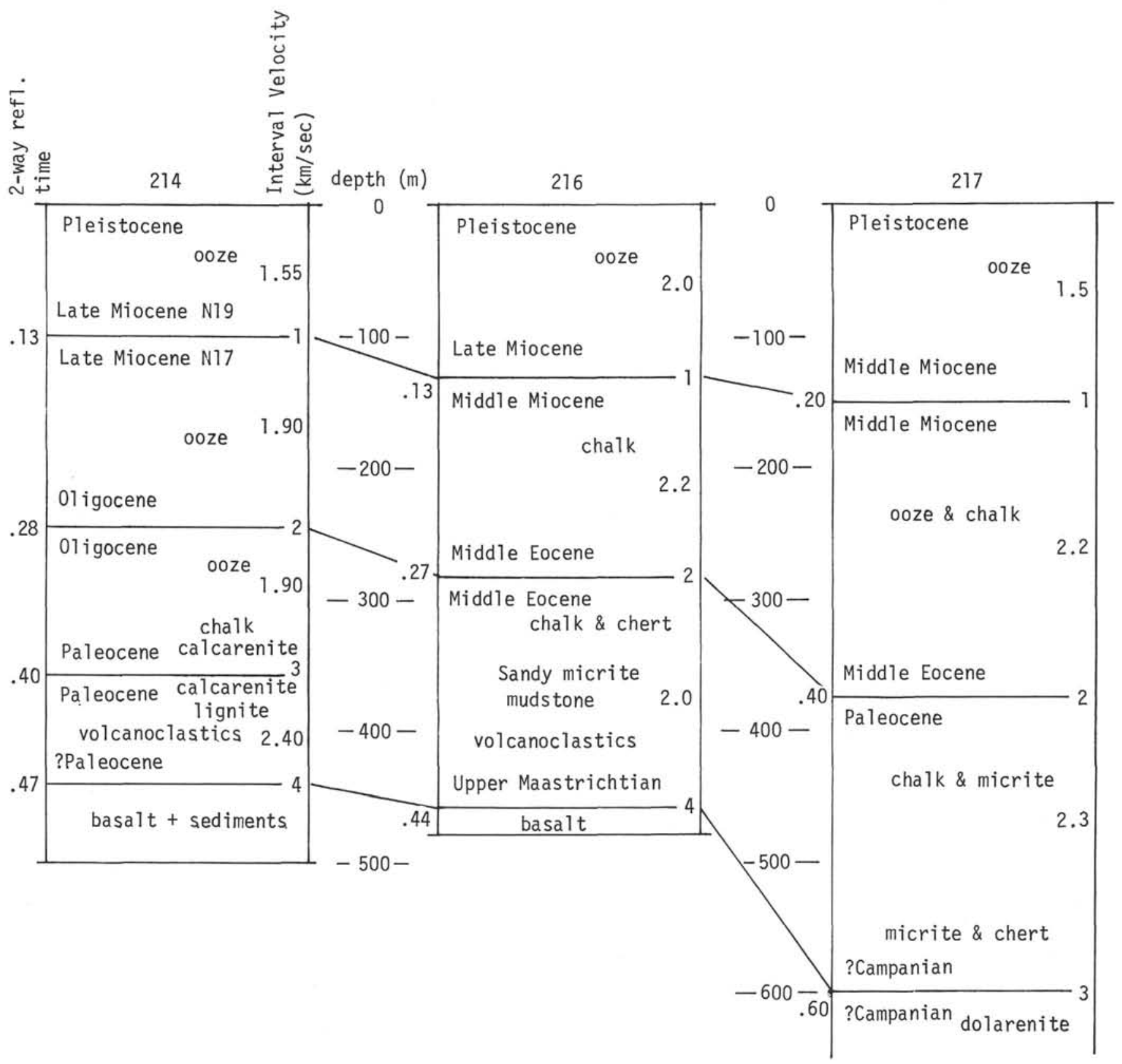

Figure 6. Continuity of reflectors but with different ages and, exceptionally, rock types along Ninetyeast Ridge.

base of a transparent surface layer and reflector 4 the basement reflector.

\section{Cocos Basin}

Beyond the ridges is the fairly flat area with a few abyssal hills of the east Cocos Basin at a general depth of $5.5 \mathrm{~km}$. Three reflectors are identified at Site 211 (Figure 4A). Reflector 1 is the boundary between a transparent Quaternary to upper Pliocene siliceous ooze-volcanic ash sequence (100 m thick) and a Pliocene turbidite sequence, reflector 2 is a surface within the turbidite sequence, and reflector 3 (seismic basement) is an andesine diabase sill, 10 meters thick, separated from basalt by 17 meters of Campanian nannofossil ooze. Ewing and Ewing (1971, p.
29) characterize this sequence as "a thin (approximately $100 \mathrm{~m}$ ) transparent layer overlying an opaque, apparently turbidite layer and a deeper transparent layer".

\section{Preliminary Conclusions}

On the track from Darwin to Site 211, extensive and coherent reflectors lie beneath the Australian continental margin, the flank of the Argo Abyssal Plain, the Roo Rise, and the area in the Cocos Basin around Site 211. The lowest reflector in the Cocos Basin was determined by drilling to be an andesine diabase sill in Late Cretaceous ooze 17 meters above flow basalt, presumably the top of layer 2. Reflectors 3 (Cocos Basin), 4 (Roo Rise), and M 

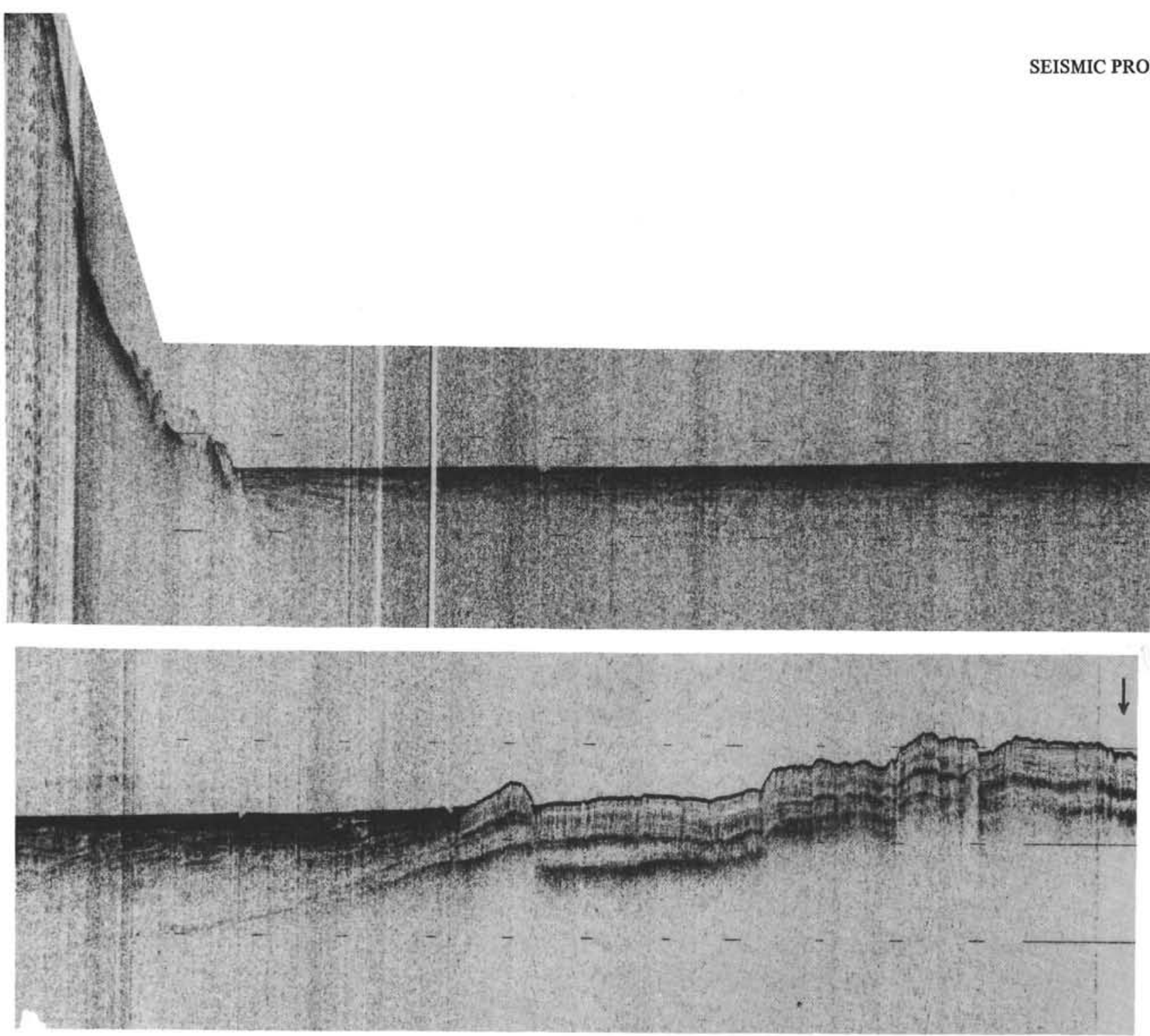

B

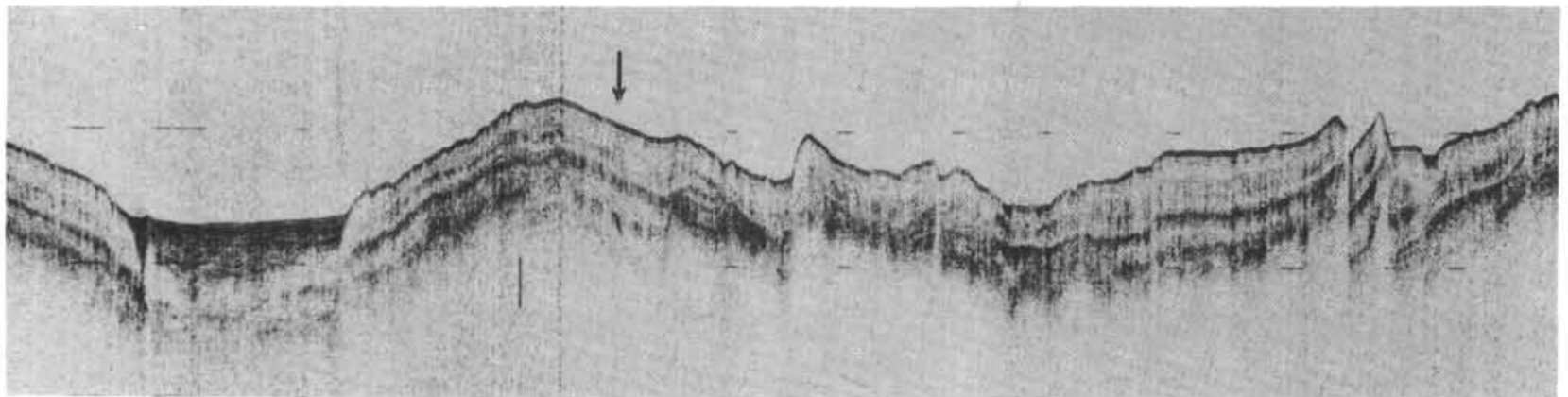

Figure 7. Reproductions of original records of the northern part of Ninetyeast Ridge and the Bengal Fan across to the continental margin of Ceylon. A: northern Ninetyeast Ridge, Site 217 (arrowed), and traverse between arrows across eastern flank of ridge and adjacent fan. B: continues from A at Site 217 (arrowed) westward to Bengal Fan. C: Bengal Fan and continental margin of Ceylon.

(Argo Plain) are similar acoustically, but this does not necessarily imply that these reflectors lie at the surface of a layer of uniform composition or age. Reflectors $\mathbf{J}$ and 1 (Roo Rise and Cocos Basin), which correspond to the base of a widespread transparent surface layer, may delimit different strata in different places. Only further drilling, as may be done in the Argo Abyssal Plain on Leg 27, will reveal the extent of these differences.
Occupying comparable situations with respect to the Indonesian arc and at roughly the same depth of $5.5 \mathrm{~km}$, the area around Site 211 and the northern flank of the Argo Abyssal Plain have, not unexpectedly, grossly similar acoustic profiles. The Roo Rise, with a depth of $2.5 \mathrm{~km}$, has a different sequence, which is interpreted as dominantly calcareous biogenous oozes deposited above the carbonate compensation level. 


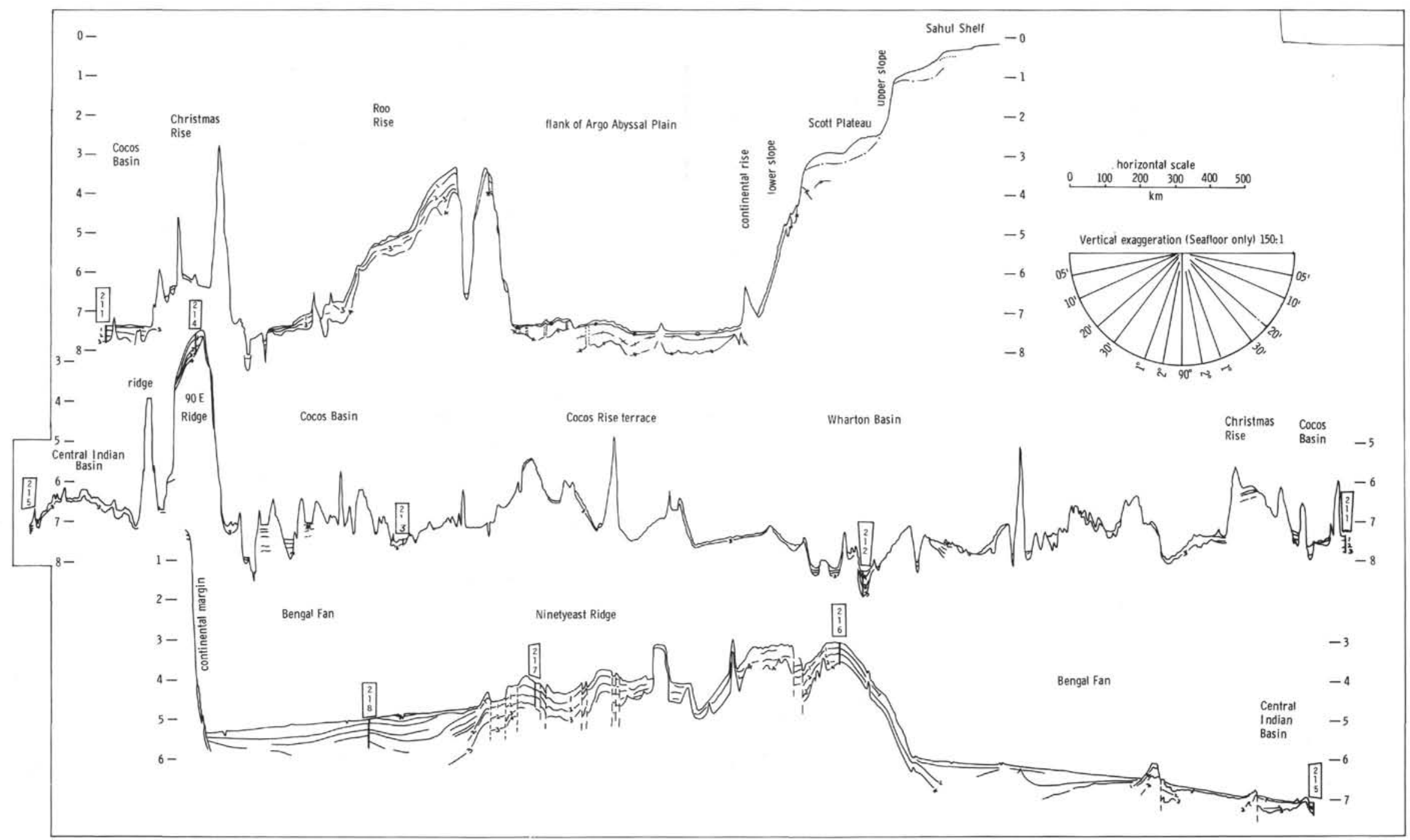




\section{SITE 211 TO SITE 212}

The track runs southwest from Site 211 across the eastern part of the Cocos Basin to its margin at the Christmas Rise, then southwards across the Wharton Basin.

\section{Cocos Basin}

The three chief reflectors at Site 211 are traceable to the foot of Christmas Rise (Figure 4A), and reflector 1 almost to the crest of the rise. The summit and the southern face of Christmas Rise itself are bare of sediment.

\section{Wharton Basin}

Between Christmas Rise and Site 212, the track crosses the rugged floor of the Wharton Basin (Figures 4B, C), whose depth ranges from $6.5 \mathrm{sec}(4875 \mathrm{~m})$, except for a ridge at 0500 hours, 26 January 1972 with a peak of 5.2 $\sec (3900 \mathrm{~m})$. This is an area of shallow basement covered with a discontinuous sheet of ponded and draped transparent sediment, as referred to by Ewing et al. (1969, p. 239). Of the three reflectors distinguished in Site 212, reflector 3 (volcanic basement) is the only one that can be traced confidently into the rest of the Wharton Basin.

\section{SITE 212 TO SITE 213}

The track runs from the northwest margin of the Wharton Basin, across an unnamed terrace and the southwestern edge of the Cocos Rise, to the southern edge of the Cocos Basin.

\section{Wharton Basin}

The part of the Wharton Basin that was traversed is comprised of sediment-filled valleys, one of which was drilled at Site 212 (Figure 4C), separated by bare hills. The reflectors in the valleys are identified with those penetrated at Site 212.

The sea floor in the valleys has a depth of $8.15 \mathrm{sec}(6112$ uncorrected meters). Northwest of 1800 hours 1 February 1972 , a scarp leads to a broad terrace that extends to 1200 hours 2 February 1972 . The terrace is broadly arched, and its depth ranges from $7.15 \mathrm{sec}(5362 \mathrm{~m})$ to $7.8 \mathrm{sec}(5850$ $\mathrm{m})$. Its surface is made of abyssal hills buried by a sheet of transparent sediment with an average thickness of $0.1 \mathrm{sec}$.

\section{Cocos Rise}

The Cocos Rise extends from 1200 hours 2 February 1972 to 0200 hours 4 February 1972 and ranges in general depth from $7.6 \mathrm{sec}(5700 \mathrm{~m})$ to $5.4 \mathrm{sec}(4050 \mathrm{~m})$, with a ridge or seamount at 0100 hours 3 February 1972 reaching to $4.8 \mathrm{sec}(3600 \mathrm{~m})$. Southeast of the seamount the rise comprises abyssal hills devoid of sediment, except near its southern margin. Northwest of the seamount, the rise is more rugged. The crest contains ponded transparent sediments in narrow valleys, and the southeast flank, from 0200 to 0630 hours 3 February 1972, has an almost continuous cover of sediments 0.1 to $0.2 \mathrm{sec}$ thick. The lower part of the northwest flank is marked by a group of seamounts or ridges (Figure 4D).

\section{Cocos Basin}

This part of the Cocos Basin lies at a general depth of $7.5 \mathrm{sec}(5625 \mathrm{~m})$ and was drilled at Site 213. Abyssal hills rise above a sheet of transparent sediment $0.15 \mathrm{sec}$ thick (Figure 4D).

\section{SITE 213 TO 214}

The track runs to Ninetyeast Ridge across an area of north-trending ridges and valleys that border the southern part of the Cocos Basin. The general level of the deep sea floor ranges from $7 \mathrm{sec}(5250 \mathrm{~m})$ to $8 \mathrm{sec}(6000 \mathrm{~m})$ and Ninetyeast Ridge almost reaches $2 \sec (1500 \mathrm{~m})$.

\section{Cocos Basin}

The sequence at Site 213 , from top to bottom, of siliceous ooze, zeolitic clay, and nannofossil ooze that overlies basalt, appears in the seismic profile as a single unbroken transparent layer and is traceable some $60 \mathrm{~km}$ westwards. The next $100 \mathrm{~km}$ (1500 to 2100 hours 7 February 1972) consists of a group of ridges and valleys that virtually lack sediment. The next area crossed, from 2100 hours 7 February 1972 to 0800 hours 8 February 1972 , consists of broader ridges and sediment-filled valleys, in which seismic penetration approaches $1 \mathrm{sec}$. The top 0.3 sec appears as well stratified highly reflective surfaces which are inferred to be turbidites. They overlie a virtually transparent interval inferred to be clay or biogenous ooze. At 0015 to 0030 hours 8 February 1972 (Figure 2), the turbidites are cut across by two transparent plugs.

A valley $8.3 \mathrm{sec}(6260 \mathrm{~m})$ deep, ponded with a mere 100 meters of sediment, separates the area of broad ridges and valleys from the eastern flank of the Ninetyeast Ridge (Figure 5A).

\section{Ninetyeast Ridge}

Besides a seamount and valley filled with draped sediment overlain by highly reflective sediments around 0900 hours 8 February 1972, the eastern flank of the Ninetyeast Ridge is comprised of a base of slumped sediment, a 1200 -meter high scarp with a slope of $15^{\circ}$, and a shoulder draped with sediment up to $0.3 \mathrm{sec}$ thick. By reference to Site 214, the sediments of the eastern flank are probably late Miocene and younger calcareous oozes.

\section{SITE 214 to SITE 215}

The track goes westward from the crest of the Ninetyeast Ridge, at Site 214, across its western flank, across an unnamed ridge or spur, and then north-northwestward across a low rise of abyssal hills in the Central Indian Basin (Figure 5A) to Site 215 near the edge of the Bengal Fan.

\section{Ninetyeast Ridge}

The sediment cap of the Ninetyeast Ridge, penetrated at Site 214, continues westward without notable change to the bare steep western flank. A sediment-covered terrace at $6 \mathrm{sec}(4500 \mathrm{~m})$ leads to narrow flat-floored valley, across a high spur with only a few pockets of sediment, to a broad rise of abyssal hills and valleys with a fairly constant $0.2 \mathrm{sec}$ of transparent sediment, which continues for some $300 \mathrm{~km}$ to Site 215. 


\section{Central Indian Basin}

The profile is interpretable, by reference to the section penetrated at Site 215 , as a nearly transparent sequence of Paleocene to lower Eocene clays and biogenous oozes (bounded by reflectors 2 and 3) on basalt and overlain by a transparent layer of siliceous ooze. The turbidites that lie between these layers (reflectors 1 and 2) at Site 215 do not extend to the more elevated sea floor south-southwestward.

\section{SITE 215 TO SITE 216}

The ship's track bears northward from Site 215 across the Central Indian Basin and the distal part of the Bengal Fan to the equator, and then east-northeastward to Site 216 on the crest of Ninetyeast Ridge.

\section{Bengal Fan and Central Indian Basin}

The stratigraphic section penetrated at Site 215 is traceable northward to 2220 hours 15 February 1972. A thin discontinuous surface transparent layer (Recent to upper Miocene siliceous ooze) overlies 0.2 to $0.3 \mathrm{sec}$ of highly reflective and well-stratified layers, presumably an upper Miocene turbidite (only the edge of which was found at Site 215) which in turn unconformably overlies discontinuous early Eocene clay and Eocene and Paleocene calcareous ooze, which rests on basaltic basement.

\section{Ninetyeast Ridge}

At Site 216, the main sedimentary reflector (2) is identified as middle Eocene chert (Figure 6), which divides the sections here into Pleistocene to middle Eocene chalk and ooze above and middle Eocene and Paleocene chalk and upper Maastrichtian tuffaceous sandstone below, all resting on basalt basement. Reflectors 2 and 4 extend west-southwestward of Site 216 and pass beneath the edge of the Bengal Fan (Figure 5C). The lower parts of the sections at Sites 215 and 216 have lower or middle Eocene sediment at the top, which can be traced in the profiles beneath the edge of the Bengal Fan, showing that at least the upper part of the fan is younger than middle Eocene. A group of hills at 1600 hours February 1972 (Figure 5B), brings near the surface a sequence that is tentatively identified as the section of basalt, Paleocene-Eocene calcareous ooze and clay, and upper Miocene turbidites encountered at Site 215, an identification supported by the continuity of reflector 1 between the hills and Site 215 . It follows from this that the upper part of the main turbidite sequence of the Bengal Fan (Reflectors A, B, C) is upper Miocene or younger.

The monotonously flat sloping surface of the Bengal Fan is broken by narrow leveed valleys (as described by Curray and Moore, 1971) at 1440 and 2115 hours 17 February 1972.

\section{SITE 216 TO SITE 217}

The track bears northward over the crest of Ninetyeast Ridge (Figure 5C, D). At Site 216 (Figure 6), a prominent middle Eocene chert is the main sedimentary reflector (2) above basalt basement (4), and, except in a few places where the chert wedges out at the flanks of basement, the chert parallels the surface of the basalt. A second sedimentary reflector (1) lies about halfway between the chert reflector and the sea floor and probably marks the boundary between ooze above and chalk below. Faults are common and equally affect the sea floor and reflectors, including basement, indicating that they must be modern.

Ewing et al. (1969, p. 239, fig. 4) illustrate a seismic section across the Ninetyeast Ridge a short distance south of Site 216. The profile is asymmetrical, with a steep east flank free of sediment and a gently sloping west flank covered with a "weakly stratified, parallel-bedded sediment penetrable to 0.3 to $0.4 \mathrm{sec} \ldots$. most of these sediments are overlapped by the Ganges cone [ $=$ Bengal Fan] sediments indicating that the latter are younger". They also show, in their fig. 3 , the thickening of sediments towards the north.

Site 217 shows that reflector 1 , corresponding to the ooze-chalk boundary, lies near the middle-late Miocene boundary and is thus roughly time-parallel at Sites 214, 216 , and 217 (see Figure 7), and that reflector 2 is middle Eocene-Paleocene and is thus markedly diachronous, as is the basement reflector, 4 .

\section{SITE 217 TO SITE 218}

The track bears westward across the crest and westward flank of the Ninetyeast Ridge to the middle of the Bengal Fan at Site 218.

\section{Ninetyeast Ridge}

The reflectors seen elsewhere beneath the Ninetyeast Ridge continue from Site 217 to the margin beneath the Bengal Fan (Figure 7B). A new reflector (4) appears only in the two eastern fault blocks. It is probably basalt, and reflector 3 is probably the dolomite penetrated at Site 217. The close parallelism of the reflectors and the sea floor seen in the three fault blocks indicates that, as seen elsewhere, the faults are modern. West of the fault at 1000 hours 29 February 1972, reflectors 2 and 3 are traceable beneath the Bengal Fan, where they converge westward, probably because this area has marked the historical boundary of more rapid carbonate deposition on the ridge and the slower abyssal deposition below the base of the Bengal Fan. Reflector 3 extends to 1700 hours 29 February 1972 and is probably either dolomite or basalt. The age of the youngest recognizable reflector (2) overlain by the fan is Paleocene.

\section{Bengal Fan}

Penetration in the overlying Bengal Fan sediments barely reached $1.0 \mathrm{sec}$. The juxtaposition of the fan and ridge reflectors between 1100 and 1200 hours 29 February 1971 (seen also on the eastern flank of the ridge in the left-hand side of Figure 7A) and the steep, presumably excavated surface of the ridge sediments indicate an angular unconformity rather than a facies change. This is reinforced by the contrast of the Neogene age of the top 773 meters of fan sediments (penetrated to the middle Miocene at Site 218) with the Paleocene age of the bulk of the neighboring ridge sediments (Site 217).

Many features of the fan system described by Curray and Moore (1971), in particular leveed channels, are visible in the profiles. 


\section{SITE 218 TO CEYLON}

\section{Bengal Fan}

Essentially the same sequence of turbidites as to the east extends westward to the foot of the continental margin of Ceylon.

\section{Margin}

The margin has a few reflectors visible at the edge of the shelf and then slopes steeply $\left(15^{\circ}\right)$ to a continental rise, which is mantled by what appear to be slide deposits. These are acoustically almost transparent, and, with acoustic basement, extend beneath the edge of the Bengal Fan.

\section{SUMMARY}

Coring through sediment sequences hitherto probed by nothing more substantial than sound waves engenders caution (if not resignation) in the marine geologist. In what follows, I hope not to have failed in distinguishing the speculative from the objective.

The part of Ewing et al.'s (1969, fig. 3) isopach map of Indian Ocean sediments traversed on Leg 22 is confirmed. The only very thick $(>1.0 \mathrm{sec})$ sediments are in the Bengal Fan (Figure 8). Elsewhere on the track of Leg 22, the sediments are moderately thick $(\geqslant 0.5 \mathrm{sec})$, as in the calcareous sequences of the Ninetyeast Ridge and (presumably) the Roo Rise and in the turbidite and biogenous ooze sequences of the Cocos Basin and (presumably) the Argo Abyssal Plain, or thin to absent $(<0.2 \mathrm{sec})$, as in the Wharton Basin, except in a few pockets of thick sediment.

Volcanic basement, turbidites, and calcareous ooze and chalk were readily identifiable from their character in seismic profiles. Siliceous ooze, cored from the surface at Sites 211,213 , and 215 , is distinctly transparent in the profiles, but not uniquely so, and it remains to be shown that the surface transparent layer on the Argo Abyssal Plain is also siliceous ooze. Zeolitic clay and brown clay (Sites $211,212,213$, and 215) were not obvious in the profiles.
The relationship of the Bengal Fan turbidites and the Ninetyeast Ridge calcareous ooze and chalk is almost certainly an unconformity, but sufficient uncertainty remains to warrant high-resolution reflection profiling over the boundary zone.

The only other serious uncertainty, hopefully to be resolved by drilling on Leg 27, is the nature of the cylindrical structure beneath the Argo Abyssal Plain.

\section{ACKNOWLEDGMENTS}

Knowledge of the acoustic sequence of the Argo Abyssal Plain was gained by study of profiles of the area at Lamont-Doherty Geological Observatory in 1971, and I acknowledge the help of J. Ewing. The profiles on which the study was based were made by T. B. Gustafson and colleagues.

\section{REFERENCES}

Curray, J. R., and Moore, D. G., 1971. Growth of the Bengal Deep-Sea Fan and denudation in the Himalayas: Geol. Soc. Am. Bull., v. 82, p. 563.

Ewing, J., and Ewing, M., 1971. Seismic reflection. In The Sea, A. E. Maxwell (Ed.): New York, (Wiley Interscience). v. 4, pt. 1.

Ewing, M., Eittreim, S., Truchan, M., and Ewing, J. I., 1969. Sediment distribution in the Indian Ocean: Deep-Sea Res. v. 16, p. 231.

Falvey, D., and Veevers, J. J., in preparation. Physiography of the northeast Indian Ocean:

Heezen, B. C., and Tharp, Marie, 1966. Physiography of the Indian Ocean: Roy. Soc. London Phil. Trans., A259, p. 137.

Laughton, A. S., Matthews, D. H., and Fisher, R. L., 1970. The structure of the Indian Ocean. In The Sea, Maxwell, A. E. (Ed.): New York (Wiley Interscience). v. 4, pt. 2, p. 543 .

Veevers, J. J., Falvey, D., Hawkins, L. V., and Ludwig, W., in preparation. Northwest Australian continental margin and adjacent abyssal areas of the northeast Indian Ocean. 